\title{
The Panomat ${ }^{\circledR}$ P-10 micro-volumetric infusion pump is suitable for continuous drug administration at minimal flow rates
}

\author{
[La pompe à perfusion microvolumétrique Panomat ${ }^{\circledR} P$-10 convient à \\ l'administration continue de médicament à débit minimal]
}

Thomas A. Neff MD, ${ }^{\star} \dagger$ Claudia Fellmann MD, ${ }^{*}$ Rudolf M. Fuechslin PhD, $\ddagger$ Andreas C. Gerber AC, ${ }^{*}$ Markus Weiss MD*

Purpose: To evaluate the performance of the Panomat ${ }^{\circledR}$ P- 10 micro-volumetric infusion pump for its use in drug administration at minimal flow rates $\left(\mu \mathrm{L} \cdot \mathrm{hr} r^{-1}\right.$; e.g., intrathecal application).

Methods: Fluid delivery at steady state conditions, and after vertical displacement of the syringe pump by $-50 \mathrm{~cm}$ was determined gravimetrically. The Panomat $\AA$ P- 10 infusion pump was evaluated at 4, 10, 20, 50 and $100 \mu \mathrm{L} \cdot \mathrm{hr}^{-1}$, and compared to a conventional syringe pump assembly at 100, 200, 500 and $1000 \mu \mathrm{L} \cdot \mathrm{hr}^{-1}$. Measurements were repeated twice with two different devices of each syringe pump system, and with two syringes. Data are reported as mean \pm SD.

Results: Steady state fluid delivery of the Panomat ${ }^{\circledR}$ P- 10 infusion pump revealed less than 5\% deviation to set flow rate at 10,20, 50 and $100 \mu \mathrm{L} \cdot h r^{-1}$, and $12 \%$ deviation at $4 \mu \mathrm{L} \cdot \mathrm{hr}^{-1}$. Mean zero-drug delivery time (ZDDT) after lowering the pump by $50 \mathrm{~cm}$ at 4 $\mu \mathrm{L} \cdot \mathrm{hr}^{-1}$ flow rate was $38.4 \pm 7.3 \mathrm{~min}$. At $100 \mu \mathrm{L} \cdot \mathrm{hr}^{-1}$ and with original infusion line ZDDT was almost 20 times shorter when compared to the conventional syringe pump assembly $(1.5 \pm 0.5$ $\min v \mathbf{2} 2.5 \pm 5.0 \mathrm{~min})$.

Conclusion: The tested Panomat ${ }^{\circledR}$ P- 10 micro-volumetric pump shows an acceptable flow accuracy as well as a low susceptibility to vertical displacement, and is therefore suitable for continuous drug administration at minimal flow rates. The technology used in this pump carries potential implications for a new generation of syringe pumps.
Objectif : Évaluer la performance de la pompe à perfusion microvolumétrique Panomat ${ }^{\circledR}$ P- 10 utilisée pour l'administration de médicaments à débit minimal ( $\mu \mathrm{L} \cdot h r^{-1}$; l'application intrathécale, par ex.).

Méthode : L'administration de liquide à l'état d'équilibre, et après le déplacement vertical de la pompe à perfusion de $-50 \mathrm{~cm}$, a été déterminée par gravimétrie. La pompe à perfusion Panomat ${ }^{\circledR} P$ - 10 a été évaluée à 4, 10,20, 50 et $100 \mu \mathrm{L} \cdot h r^{-1}$ et comparée à une pompe à perfusion classique à 100, 200, 500 et $1000 \mu \mathrm{L} \cdot \mathrm{hr}^{-1}$. Les mesures ont été faites deux fois avec deux appareils différents pour chaque système de pompe à perfusion et avec deux seringues. Les données sont décrites par la moyenne \pm l'écart type.

Résultats : L'administration de liquide à l'état d'équilibre, de la pompe à perfusion Panomat ${ }^{\circledR} P$ - 10 , présentait moins de $5 \%$ de déviation du débit fixé à 10,20,50 et $100 \mu \mathrm{L} \cdot h^{-1}$, et $12 \%$ de déviation à 4 $\mu L \cdot h^{-1}$. La durée moyenne de perfusion nulle (DPN), après avoir abaissé la pompe de $50 \mathrm{~cm}$, à $4 \mu \mathrm{L} \cdot \mathrm{h}^{-1}$ a été de $38,4 \pm 7,3 \mathrm{~min}$. À 100 $\mu L \cdot h^{-1}$, et avec les tubulures de perfusion d'origine, la DPN a été presque 20 fois plus courte qu'avec le système classique de pompe à perfusion ( $1,5 \pm 0,5 \mathrm{~min}$ vs 28,5 $\pm 5,0 \mathrm{~min})$.

Conclusion : La pompe microvolumétrique Panomat ${ }^{\circledR} P$ - 10 démontre une fiabilité du débit acceptable ainsi qu'une faible susceptibilité au déplacement vertical. Elle convient donc à l'administration continue de médicament à débit minimal. La technologie utilisée pour cette pompe comporte des implications potentielles pour une nouvelle génération de pompes à perfusion.

From the Department of Anaesthesia, ${ }^{*}$ University Children's Hospital Zurich, Switzerland; the Department of Anaesthesia, $\dagger$ University Hospital Zurich, Switzerland; and the Research Department, $\ddagger$ BioMIP, Schloss Birlinghoven, St. Augustin, Germany

Disclosure statement: The manufacturer (Disetronic Medical Systems AG, Burgdorf, Switzerland) provided two Panomat ${ }^{\circledR}$ - P-10 microvolumetric infusion pumps and infusion lines for the study without charge. The authors do not hold any agreement on the device and did not receive any financial support from the manufacturer for the study.

Address correspondence to: Dr. Markus Weiss, Department of Anaesthesia, University Children's Hospital, Steinwiesstrasse 75, CH-8032

Zurich, Switzerland. Phone: +41 126677 53; Fax:+41 1266 71 68; E-mail: markus.weiss@kispi.unizh.ch

Accepted for publication April 25, 2002.

Revision accepted August 14, 2002. 


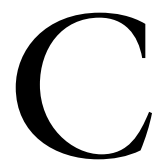

ONTINUOUS application of very low flow rates challenges conventional syringe pump infusion systems, and the need for new technologies has been suggested. ${ }^{1}$ Recently, we were involved in the continuous intrathecal application of baclofen (Lioresal ${ }^{\circledR}$ ) for children suffering from spasticity of cerebral origin. ${ }^{2}$ An upcoming therapeutic strategy in these children includes in a first step the percutaneous placement of a spinal catheter (by the pediatric anesthesiologist) connected to an external pump. Initial doses of 50 $\mu \mathrm{g} \cdot$ day $^{-1}$ baclofen $\left(2 \mu \mathrm{g} \cdot \mathrm{hr}^{-1}\right.$ correspond to approximately $4 \mu \mathrm{L} \cdot \mathrm{hr}^{-1}$ ) are administered by the external syringe pump. Doses are further increased to $80 \mu \mathrm{g}-$ $800 \mu \mathrm{g} \cdot \mathrm{day}^{-1}$ (average need $150 \mu \mathrm{g} \cdot \mathrm{day}^{-1}$ ) according to the patient's muscle tone and the side effects. ${ }^{3}$ After the effective dose of intrathecal baclofen has been established in an individual patient, a permanent programmable pump device can be implanted into the abdominal subcutaneous tissue.

Because of the known specific problems with conventional syringe pumps at low flow rates we evaluated the Panomat ${ }^{\circledR}$ P-10 micro-volumetric (PMV) infusion pump for intrathecal baclofen administration. The pump was originally designed for subcutaneous long-term application of insulin or iron-chelators. The manufacturer claims precise flow rates down to 1 $\mu \mathrm{L} \cdot \mathrm{hr}^{-1}$. However, no data are available about its performance during vertical displacement which in conventional syringe infusion pumps can lead to harmful interruption of drug delivery or to bolus injection. ${ }^{1,4,5}$ Fluid delivery was therefore assessed after negative vertical displacement at minimal flow rates and compared to a common conventional syringe pump infusion line assembly.

\section{Methods}

\section{The PMV infusion pump}

The PMV infusion pump (Panomat ${ }^{\circledR}$ P-10, Disetronic Medical Systems AG, Burgdorf, Switzerland) is a small portable battery-operated $(2 \times$ 3 volt silver oxide cell) infusion device (Figure 1A). A specially designed $10-\mathrm{mL}$ plastic syringe (Plastic Cartridge Set $10 \mathrm{~mL}$; Disetronic Medical Systems AG, Burgdorf, Switzerland) is used. After loading the plastic cartridge with fluid the plastic filling rod (Figure 1B) is replaced by a metallic threaded piston rod with cylindrical drive nut (Figure 1C/D) fitting into the rubber piston. The plastic cartridge with the threaded piston rod is then placed into the pump driver and the pump closed with a screw adapter. Any rotation of the metallic threaded piston rod within the drive nut results in forward movement of the rubber piston.

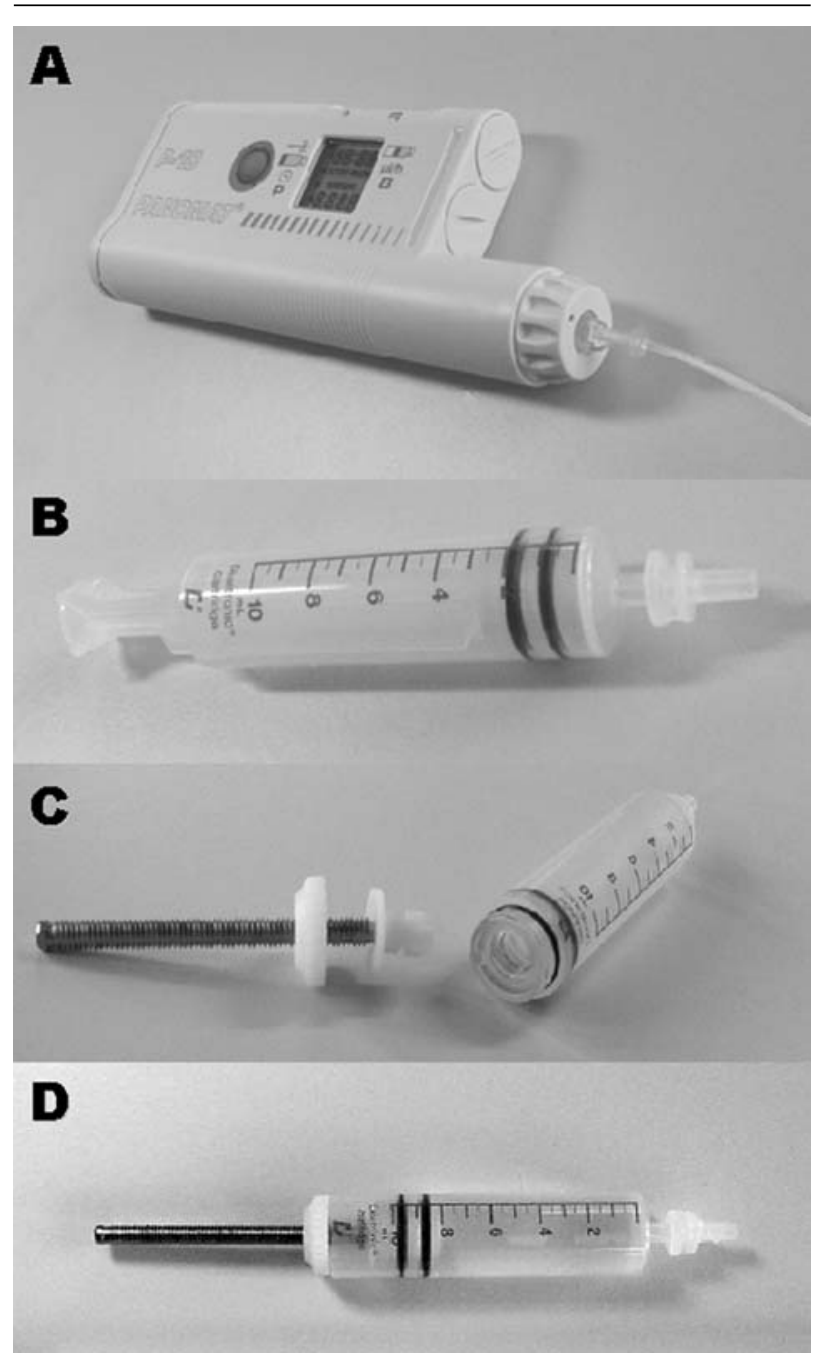

FIGURE 1 A, Portable, battery-operated micro-volumetric infusion pump Panomat ${ }^{\circledR}$ P-10 with LCD display (weight with batteries $150 \mathrm{~g} /$ dimensions $132 \times 60 \times 23 \mathrm{~mm}$ ) allows programmable flow rates of $0 \mu \mathrm{L} \cdot \mathrm{hr}^{-1}-1000 \mu \mathrm{L} \cdot \mathrm{hr}^{-1}$, bolus application of 0 $\mu \mathrm{L}-300 \mu \mathrm{L}$, time lock feature, and limitation of number of boluses per hour. B, 10-mL plastic cartridge with filling rod. C/D, Drive nut of the threaded piston rod placed on the plastic cartridge.

A specially designed stiff, low compliant Panomat ${ }^{\circledR}$ infusion line (extension set PE $110 \mathrm{~cm}$; Maersk Medical, DK, Ref. 300.0294) was screwed to the cartridge and prefilled by the prime catheter option. Care was taken to avoid air and to extrude any remaining air bubbles from the cartridge and the infusion line.

Flow rates of $0 \mu \mathrm{L} \cdot \mathrm{hr}^{-1}-1000 \mu \mathrm{L} \cdot \mathrm{hr}^{-1}$ and boluses of $0 \mu \mathrm{L}-300 \mu \mathrm{L}$ can be set. Additional features are time lock and limitation of bolus frequency. A contin- 


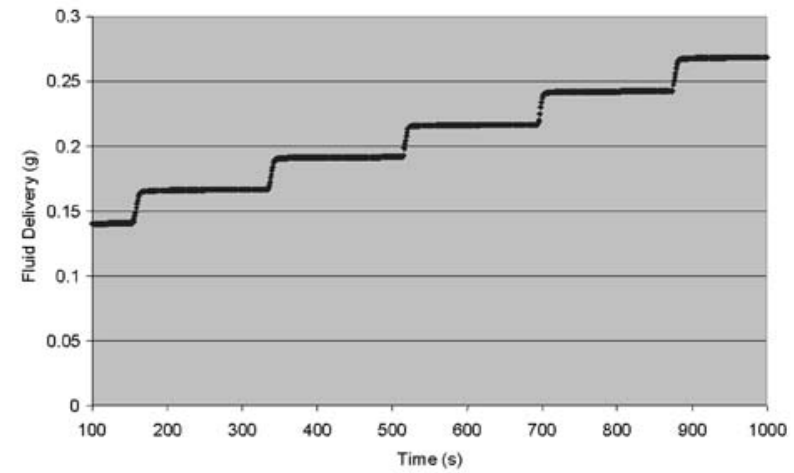

FIGURE 2 Cyclic fluid delivery by the Panomat ${ }^{\circledR}$ P-10 infusion pump at $500 \mu \mathrm{L} \cdot \mathrm{hr}^{-1}$ flow rate. The pump driver turns the threaded piston rod periodically every three minutes resulting in a small fluid bolus according to the programmed flow rate per hour (e.g., $25 \mu \mathrm{L}$ bolus per cycle at $500 \mu \mathrm{L} \cdot \mathrm{hr}^{-1}$ ).

uous flow rate was established by delivering a small bolus every three minutes (three-minute bolus varies according to the preset flow rate).

\section{Conventional syringe pump infusion system}

The conventional syringe pump assembly consisted of the Braun Perfusor ${ }^{\circledR}$ compact syringe pump (B. Braun, Melsungen, Germany) combined with a low compliant 50-mL infusion syringe (syringe $50-60 \mathrm{~mL}$, Codan Medical Aps, Rodby, DK) and the Panomat ${ }^{\circledR}$ infusion line.

\section{Measurements}

For all measurements a gravimetric in vitro set-up was used as published earlier. ${ }^{6}$ The distal end of the Panomat ${ }^{\circledR}$ or Injectomat ${ }^{\circledR}$ infusion line was connected to an additional stiff infusion line (PE-infusion line, Clinico Medical GmbH, Bad Hersfeld, Germany) immersed with its distal tip by $13 \mathrm{~cm}$ in a sampling glass filled with distilled water. A thin layer of oil covered the water surface to avoid fluid evaporation. Assuming a specific weight of distilled water of $\mathrm{l} \mathrm{g} \cdot \mathrm{mL}^{-1}$ at room temperature fluid delivery $\left(\mu \mathrm{L} \cdot \mathrm{hr}^{-1}\right)$ into the sampling glass was gravimetrically determined using an electronic balance (AG 204-Delta-Range $\AA$, Mettler Toledo, Schwerzenbach, Switzerland; sensitivity $0.0001 \mathrm{~g}$ ). Data were recorded at a sample rate of one second using a purpose-written software (MCPS V2.6-CAD, Software GmbH, Mönchengladbach, Germany).
TABLE I Continuous flow rate accuracy of the Panomat ${ }^{\circledR}$ P-10 micro-volumetric infusion pump at different flow rates (one-hour time period measurements)

\begin{tabular}{lll}
\hline Flow rate preset & Flow rate measured & $\begin{array}{l}\text { Deviation to preset } \\
\text { flow rate } \\
\%\end{array}$ \\
$\mu L \cdot h r^{-1}$ & $\mu L \cdot h r^{-1}$ & -12.1 \\
4 & $3.5 \pm 0.2$ & -4.0 \\
10 & $9.6 \pm 0.2$ & -2.0 \\
20 & $19.6 \pm 0.6$ & -1.2 \\
50 & $49.4 \pm 1.4$ & -0.6 \\
\hline 100 & $99.4 \pm 3.1$ & \\
\hline
\end{tabular}

Data are presented as mean $\pm \mathrm{SD}$.

First, continuous fluid delivery of the PMV infusion pump was determined at infusion rates of 4,10 , 20,50 , and $100 \mu \mathrm{L} \cdot \mathrm{hr}^{-1}$ each over a one-hour time period after establishing steady state flow. For the measurements the syringe outlet was adjusted to the level of the immersed infusion line tip.

To determine a relative value for the static syringe pump-infusion line compliance, retrograde aspiration volume after lowering the syringe pump by $50 \mathrm{~cm}$ was measured while pump was in hold position.

Second, at steady state flow conditions zero-drug delivery time (ZDDT; time period between lowering of the syringe pump and reattainment of initial weight on the balance) was determined after lowering the pump by $50 \mathrm{~cm}$ below the level of the immersed infusion line tip. Experiments were performed at infusion rates of 4 , $10,20,50$, and $100 \mu \mathrm{L} \cdot \mathrm{hr}^{-1}$ in the PMV infusion pump, and at $100,200,500$ and $1000 \mu \mathrm{L} \cdot \mathrm{hr}^{-1}$ in the conventional syringe pump infusion line assembly.

Third, to study the effect of infusion line compliance on ZDDT at very low infusion rates, measurements with the PMV infusion pump were repeated by replacing the original Panomat ${ }^{\circledR}$ infusion line by a soft, more compliant $150 \mathrm{~cm}$ infusion line (Injectomat ${ }^{\circledR}$ infusion line; Fresenius $A G, B a d$ Homburg, Germany).

All experiments were performed at $22-24^{\circ} \mathrm{C}$ ambient temperature in duplicates using two individual pumps, and two different syringes with infusion lines of each brand (eight measurements).

\section{Data analysis}

Static compliance and ZDDT were compared across the three syringe pump infusion line assemblies by Wilcoxon-Mann-Whitney-Test. Data are presented as mean \pm SD. A $P$ value of less than 0.05 was considered statistically significant. 
TABLE II Static compliance and zero-drug delivery time (ZDDT) at different flow rates after lowering the pump by $50 \mathrm{~cm}$

\begin{tabular}{|c|c|c|c|}
\hline $\begin{array}{l}\text { Pump type } \\
\text { extension line } \\
\text { (static compliance) }\end{array}$ & $\begin{array}{l}\text { Panomat } \AA \text { P-10 } \\
\text { Panomat } \AA \text { infusion line } \\
\left(0.018 \pm 0.004 \mu \mathrm{L} \cdot \mathrm{cm}^{-1} \mathrm{H}_{2} \mathrm{O}\right)\end{array}$ & 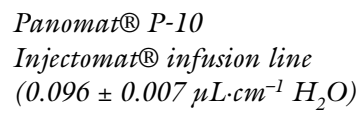 & $\begin{array}{l}\text { Braun Perfusor } \AA \text { compact } \\
\text { Panomat } \AA \text { infusion line } \\
\left(0.20 \pm 0.017 \mu \mathrm{L} \cdot \mathrm{cm}^{-1} \mathrm{H}_{2} \mathrm{O}\right)\end{array}$ \\
\hline Flow rate & ZDDT & ZDDT & ZDDT \\
\hline$\mu \mathrm{L} \cdot \mathrm{hr}^{-1}$ & $\min$ & $\min$ & $\min$ \\
\hline 4 & $38.4 \pm 7.3$ & $166.1 \pm 12.8$ & -- \\
\hline 10 & $10.6 \pm 2.9$ & $49.3 \pm 9.3$ & -- \\
\hline 20 & $4.7 \pm 0.7$ & $19.9 \pm 2.0$ & -- \\
\hline 50 & $2.8 \pm 1.1$ & $6.0 \pm 0.7$ & - \\
\hline 100 & $1.5 \pm 0.5$ & $4.0 \pm 0.9$ & $28.5 \pm 5.0$ \\
\hline 200 & - & - & $13.0 \pm 1.8$ \\
\hline 500 & - & - & $5.2 \pm 1.0$ \\
\hline 1000 & -- & -- & $2.3 \pm 0.3$ \\
\hline
\end{tabular}

Data are presented as mean $\pm \mathrm{SD}$.

\section{Results}

Continuous flow data of the PMV infusion pump are presented in Table I. Static compliance differed significantly between the two syringe pump types and the two infusion line assemblies (PMV pump with two different extension lines). The static compliance of the PMV device with its original infusion line was 11 times smaller than that of the conventional infusion pump assembly $(P<0.005)$. A six-fold increase was measured when the original infusion line of the PMV system was replaced by the Injectomat ${ }^{\circledR}$ infusion line $(P<0.005$; Table II $)$.

ZDDT for the PMV infusion pump with the original infusion line at $4 \mu \mathrm{L} \cdot \mathrm{hr}^{-1}$ infusion rate ranged from 38.4 $\pm 7.3 \mathrm{~min}$ and increased to $166.1 \pm 12.8 \mathrm{~min}$ when the Injectomat ${ }^{\circledR}$ infusion line was used (Table II). At 100 $\mu \mathrm{L} \cdot \mathrm{hr}^{-1}$ with the original infusion line, ZDDT was about 19 times shorter compared to the conventional syringe pump infusion line assembly $(1.5 \pm 0.5 \mathrm{~min} v s$ $28.5 \pm 5.0 \mathrm{~min} ; P<0.005)$ and increased to $4.0 \pm 0.9$ min with the Injectomat ${ }^{\circledR}$ infusion line $(P<0.001)$.

\section{Discussion}

The present study investigates the overall performance of a special-purpose micro-volumetric infusion pump at very low flow rates and after vertical displacement of the infusion pump assembly. Since absolute amounts of fluid delivery are of less importance in intensive care medicine than continuity of drug administration, conventional syringe pumps are primarily designed as titration elements particularly when used with inotropic, vasoactive, and endocrine drugs. Conversely, absolute amounts at very low infusion rates have a higher priority than continuity of drug delivery for intrathecal drug administration (e.g., baclofen). The tested PMV infusion device provides very accurate fluid delivery even at smallest infusion rates $\left(\mu \mathrm{L} \cdot \mathrm{hr}^{-1}\right)$ according to the manufacturers specifications of $<5 \%$ flow inaccuracy at maximum delivery rate $\left(=1000 \mu \mathrm{L} \cdot \mathrm{hr}^{-1}\right)$, and proportionally larger deviations at smaller flow rates. Thus the device is particularly suitable for continuous intrathecal drug administration, e.g., baclofen medication in children suffering from spasticity of cerebral origin.

Continuous fluid delivery from conventional syringe infusion pumps is known to be a critical issue after vertical displacement of the syringe pump infusion line assembly, and is caused by changes in hydrostatic pressure within the infusion system. ${ }^{1,4}$ Particularly at low infusion rates, these changes lead to prolonged gravitational siphoning of the infusion solution into the system when the pump device is lowered. Below $1 \mathrm{~mL} \cdot \mathrm{hr}^{-1}$, drug delivery may be delayed or interrupted for several minutes up to hours after vertical displacement of the infusion pump. ${ }^{5}$ ZDDT (time with suspended drug delivery) raises with decreasing infusion rates following roughly a $1 / \mathrm{X}$ ratio (e.g., halving the infusion rate doubles the ZDDT). ${ }^{5}$

If the tested conventional syringe pump infusion line assembly, which proved to have the best performance compared to earlier investigations, had been used for the above mentioned intrathecal drug administration at $4 \mu \mathrm{L} \cdot \mathrm{hr}^{-1}$, and assuming that halving the infusion rate doubles the ZDDT, a calculated ZDDT of approximately $13 \mathrm{hr}$ would have resulted. ${ }^{6-8}$ Besides interruption of drug administration, it is con- 
ceivable that large ZDDTs and retrograde aspiration of blood into a catheter carries the potential risk of accidental catheter occlusion.

Several characteristics may explain the flow accura$\mathrm{cy}$, the outstanding low system compliance and performance after vertical displacement of the PMV infusion pump system:

Instead of the widely used $50-\mathrm{mL}$ syringes in conventional syringe pumps the PMV infusion device is provided with a specially designed $10-\mathrm{mL}$ plastic cartridge. This smaller size has reduced compressible areas, and the avoidance of a compressible rubber seal plunger decreases syringe compliance substantially. ${ }^{6,8}$ Furthermore, the threaded metallic piston rod, the firm fit of the drive nut into the cartridge body (closed with a screw adapter) and the syringe driver form a stiff and low compliant functional unit. ${ }^{7}$ Infusion line compliance may further influence pump performance substantially. ${ }^{9}$ The importance of using the original stiff, low compliant tube extension set with a very small inner diameter was demonstrated by the four-fold increase in ZDDT when it was replaced by the soft, more compliant Injectomat ${ }^{\circledR}$ infusion line (Table II). ${ }^{9}$ The design of the tested PMV infusion device results in minimal mechanical gaps, a low overall system compliance and contributes to its optimized functional performance. ${ }^{10}$

Even though this device may be very advantageous in terms of high flow accuracy and low susceptibility to vertical displacement several points with respect to its potential use in pediatric anesthesia and intensive care medicine must be mentioned: First, in case of accidental occlusion, the device's cut-out pressure is set at 4 bar, resulting in a maximum back-up bolus of $80 \mu \mathrm{L}$ (manufacturer's specifications). This threshold appears excessively high but confirms our measurements of the system compliance $\left(0.02 \mu \mathrm{L} \cdot \mathrm{cm}^{-1} \mathrm{H}_{2} \mathrm{O}\right)$. Second, due to the specific pump motor design an appropriate liquid bolus is released stepwise every three minutes (Figure 2 ). This fluid delivery strategy is not suitable for inotropic or vasoactive medication since their short half-life (usually one to two minutes) would result in a periodic discontinuity of the desired drug effect. Finally, although the small $10-\mathrm{mL}$ cartridge contributes substantially to the advantages of this specific pump device it would require frequent refilling maneuvers if used for higher fluid delivery rates.

There are some limitations of the present study. First, measurements of start up delay and comparison of the performance after vertical syringe pump displacement at higher flow rates were not accessible to our evaluation because of the cyclic fluid release every three minutes in the PMV pump device. Second, even though some conventional infusion pumps may be loaded with smaller
10-mL syringes, we compared the 10-mL PMV infusion pump with a $50-\mathrm{mL}$ syringe infusion pump, which represents the widely used, standard device in pediatric anesthesia and intensive care medicine.

In conclusion, the tested PMV infusion pump shows excellent flow accuracy as well as a low susceptibility to negative vertical displacement, and is therefore suitable for drug administration at very low flow rates (e.g., intrathecal as in the case described). The technology used in this pump carries potential implications for a new generation of syringe pumps for its use in pediatric and neonatal intensive care medicine and anesthesia.

\section{Acknowledgements}

We thank Dr. Vidya Sarma, Department of Pathology, University of Michigan Medical School, Ann Arbor, MI, USA for linguistic advice.

\section{References}

1 Cook RI. Syringe pump assemblies and the natural history of clinical technology (Editorial). Can J Anesth 2000; 47: 929-35.

2 Albright AL, Barron WB, Fasick MP, Polinko P, Janosky $J$. Continuous intrathecal baclofen infusion for spasticity of cerebral origin. JAMA 1993; 270: 2475-7.

3 Gilmartin R, Bruce D, Storrs BB, et al. Intrathecal baclofen for management of spastic cerebral palsy: multicenter trial. J Child Neurol 2000; 15: 71-7.

4 Lonnqvist PA. How continuous are continuous drug infusions? (Editorial). Intensive Care Med 2000; 26: 660-1.

5 Kern H, Kuring A, Redlich U, et al. Downward movement of syringe pumps reduces syringe output. Br J Anaesth 2001; 86: 828-31.

6 Weiss M, Hug MI, Neff T, Fischer J. Syringe size and flow rate affect drug delivery from syringe pumps. Can J Anesth 2000; 47: 1031-5.

7 Neff TA, Fischer JE, Schulz G, Baenziger O, Weiss M. Infusion pump performance with vertical displacement: effect of syringe pump and assembly type. Intensive Care Med 2001; 27: 287-91.

8 Weiss M, Fischer J, Neff T, Baenziger O. The effects of syringe plunger design on drug delivery during vertical displacement of syringe pumps. Anaesthesia 2000; 55 : 1094-8.

9 Weiss $M$, Banziger O, Neff T, Fanconi S. Influence of infusion line compliance on drug delivery rate during acute line loop formation. Intensive Care Med 2000; 26: 776-9.

10 Lonnqvist PA, Lofqvist B. Design flaw can convert commercially available continuous syringe pumps to intermittent bolus injectors. Intensive Care Med 1997; 23: 998-1001. 